\title{
PEMASARAN OLAHRAGA MELALUI BERBAGAI EVENT OLAHRAGA
}

\author{
Oleh: Yustinus Sukarmin \\ Dosen Jurusan Pendidikan Kesehatan dan Rekreasi FIK UNY
}

\section{Abstrak}

Pada era globalisasi ini muncul terminologi sportainment yang memberikan peneguhan bahwa olahraga bukan lagi sekadar sebuah tontonan melainkan sebuah industri hiburan dan bisnis pertunjukkan yang mampu menghadirkan ribuan penonton dan jutaan pemirsa. Kini, ada tiga event olahraga yang menjadi ikon global, yaitu pertandingan sepak bola Piala Dunia, lomba balap mobil Formula 1, dan pertandingan olahraga multievent Olimpiade.

Olahraga jika dikelola secara profesional dapat mendatangkan keuntungan ekonomi di samping keuntungan nonekonomi. Olimpiade Los Angeles 1984 merupakan Olimpiade Modern pertarna yang menerapkan pendekatan logika ekonomi melalui sport business dengan melibatkan banyak sponsor. Keuntungan yang berhasil dikumpulkan dari kegiatan multievent empat tahunan itu sebesar US \$223 juta.

Keberhasilan suatu negara menyelenggarakan event olahraga ini tidak terlepas dari peran pemasaran. Untuk memasarkan sebuah event olahraga diperlukan strategi khusus yang dikenal dengan bauran pemasaran, yaitu kiat kelompok pemasaran yang digunakan untuk mencapai sasaran pemasarannya dalam pasar sasaran. Media massa punya peran penting dalam menumbuhkan brand image tentang sebuah produk tertentu kepada konsumen melalui tayangan event olahraga.

Kata Kunci: pemasaran olahraga, event olahraga

Siapa sangka, olahraga yang pada awalnya hanya merupakan suatu kegiatan pengisi waktu luang dan media untuk memperoleh kesehatan, kini menjadi sebuah bisnis raksasa yang menggiurkan. Azra (2010: 1) mengatakan turnamen olahraga tingkat dunia, seperti Piala Dunia dan Olimpiade, dalam beberapa dasa warsa terakhir ini bukan lagi sekadar peristiwa akbar olahraga, melainkan telah menjadi ajang bisnis multimiliar dolar. Masih ingatkah dengan Olimpiade Los Angeles 1984? Ada apa dengan Olimpiade Los Angeles? Olimpiade Los Angeles merupakan Olimpiade Modern pertama yang menerapkan pendekatan logika ekonomi melalui sport business (Mutohir, 2004: 36). Pernyataan tersebut memberikan bukti bahwa olahraga jika dikelola secara profesional dapat mendatangkan 
keuntungan ekonomi di samping nonekonomi. Olimpiade Los Angeles 1984 berhasil meraup keuntungan sebesar US $\$ 223$ juta.

Keuntungan itu diperoleh dari mana? Pergelaran Olimpiade Los Angeles menghabiskan biaya sebesar US $\$ 505$ juta. Dari jumlah tersebut, hampir separuhnya telah tertutup dari hak siar yang dibeli oleh jaringan televisi ABC sebesar US \$225 juta. Sejumlah besar perusahaan (32 perusahaan) telah menjadi sponsor dengan nilai US \$413 juta. Selain itu, panitia juga menerima berbagai bantuan yang diberikan untuk membangun fasilitas olahraga. Pembangunan velodrom dan kedai makan-minum ditanggung oleh perusahaan 7 Eleven. Kolam renang senilai US \$4 juta sepenuhnya dibiayai oleh McDonald. Pakaian seragam atlet dan pelatih yang berjumlah 700 orang dan panitia yang seluruhnya berjumlah 40.000 orang disediakan oleh Levis. Sistem komputerisasi yang menggunakan 200 set komputer semuanya disediakan oleh IBM.

Keberhasilan Olimpiade Los Angeles membangkitkan minat negara-negara lainnya yang saling berebut untuk menjadi tuan rumah suatu event olahraga, baik yang bersifat multievent, seperti Asian Games dan Olympic Games, maupun yang bersifat singleevent, seperti Piala Dunia dan balap mobil Formula 1. Pada saat ini, menurut Wakil Presiden Pemasaran Global LG Electronics, Andrew Barret, ada tiga event olahraga yang menjadi ikon global yaitu: Piala Dunia, Olimpiade, dan balap mobil Formula 1 (Burhanudin, 2010: 33). Dapat ikut ambil bagian dalam tiga event tersebut menjadi keuntungan potensial bagi perusahaan yang terpilih sebagai sponsor. Dengan menjadi sponsor dari berbagai event olahraga, dalam tiga belas tahun terakhir ini, angka penjualan LG di seluruh dunia berkembang dari US $\$ 100$ juta menjadi US $\$ 43,3$ miliar.

Peristiwa olahraga menyimpan potensi keuntungan yang menggiurkan di dalamnya. Para pengusaha akan rela menginvestasikan dana jutaan dolar untuk memasang iklan dalam tayangan olahraga. Mereka sadar bahwa memasang iklan dalam siaran olahraga yang ditonton oleh jutaan pemirsa merupakan cara yang sangat efektif untuk meningkatkan angka penjualan. Kondisi ini disadari betul oleh pemilik media massa, sehingga mereka berlomba-lomba untuk mendapatkan hak siar kegiatan yang mendunia. Mereka memunyai optimisme bahwa keuntungan yang diperoleh akan berlipat ganda. Sebagai ilustrasi dapat dikemukakan di sini bagaimana perusahaan Adidas dan Nike meraup keuntungan dalam Piala Dunia 2010 Afrika Selatan. Adidas selaku sponsor resmi memperkirakan keuntungan mencapai 1,9 juta dolar AS. Perusahaan asal Jerman itu juga menjual 12 juta kaos timnas Jerman, lebih dari 1 juta kaos Meksiko, Argentina, Afrika Selatan, dan sekitar 1 juta kaos Spanyol. Nike juga menikmati keuntungan sebesar 39 persen pada kuartal pertama (ANG, 2010: 31).

Agar dapat mendatangkan keuntungan ekonomi atau nonekonomi, event olahraga, seperti Piala Dunia dan Olimpiade, harus dikelola dengan pendekatan bisnis yang melibatkan sebanyak mungkin sponsor (Mutohir, 2004: 38). Dalam kaitannya dengan hal ini, peran pemasaran sangatlah penting karena merupakan salah satu faktor kunci penentu keberhasilan bisnis. Apa itu pemasaran, apa pula pemasaran olahraga itu, 
bagaimana strategi dalam pemasaran olahraga, bagaimana pula peran media dalam pemasaran olahraga? Uraian selanjutnya akan difokuskan pada hal-hal yang merupakan jawaban atas pertanyaan-pertanyaan tersebut di atas.

\section{PEMBAHASAN}

\section{Event Olahraga dalam Industri Olahraga}

Salah satu unsur penting industri olahraga yang dapat berkembang menjadi orientasi industri adalah event. Event olahraga mengandung dua aspek sebagai faktor penting yang menjamin bergulirnya industri di bidang keolahragaan, yaitu bagaimana membangun olahraga (internal) dan bagaimana menjual olahraga (eksternal). Aspek internal melibatkan partisipasi masyarakat dan perangkat infrastruktur (tools), sebagai pembangun event olahraga (entertainer), sedangkan aspek eksternal meliputi publik, media, dan partner, sebagai penjual event olahraga yang bermutu (IAAF, 2003, dalam Lumintuarso, 2005: 7).

Partisipasi berarti suatu upaya untuk mempertunjukkan partisipan olahraga dengan mengembangkan kualitasnya dengan tujuan untuk membuat olahraga bernilai tinggi. Tools adalah semua yang terlibat membantu partisipan, seperti: organisasi, infrastruktur, training, dan komunikasi untuk menjamin pelaksanaan event, sehingga dapat memberikan citra yang positif ditinjau dari segi atraktivitas, sportivitas, dan prestasi.

Sasaran eksternal adalah bagaimana menjual olahraga dengan mengacu pada aspek publik, yaitu masyarakat umum yang mengikuti event dan kegiatan olahraga secara langsung atau melalui media. Media merupakan alat bantu olahraga untuk menghubungkan dengan publik melalui sistem hubungan kerja sama (hak siar, berita, dll.). Media dapat berupa media elektronik, cetak, dan fotografi, serta teknologi informasi, yang meliputi internet, press, broadcasting. Partner adalah kelompok masyarakat yang menyumbangkan uang/dana untuk olahraga. Mereka itu adalah sponsor, pemerintah, dan pemegang saham penyiaran. Hubungan antara event olahraga dan faktor pendukung dapat dilihat dalam Gambar 1.

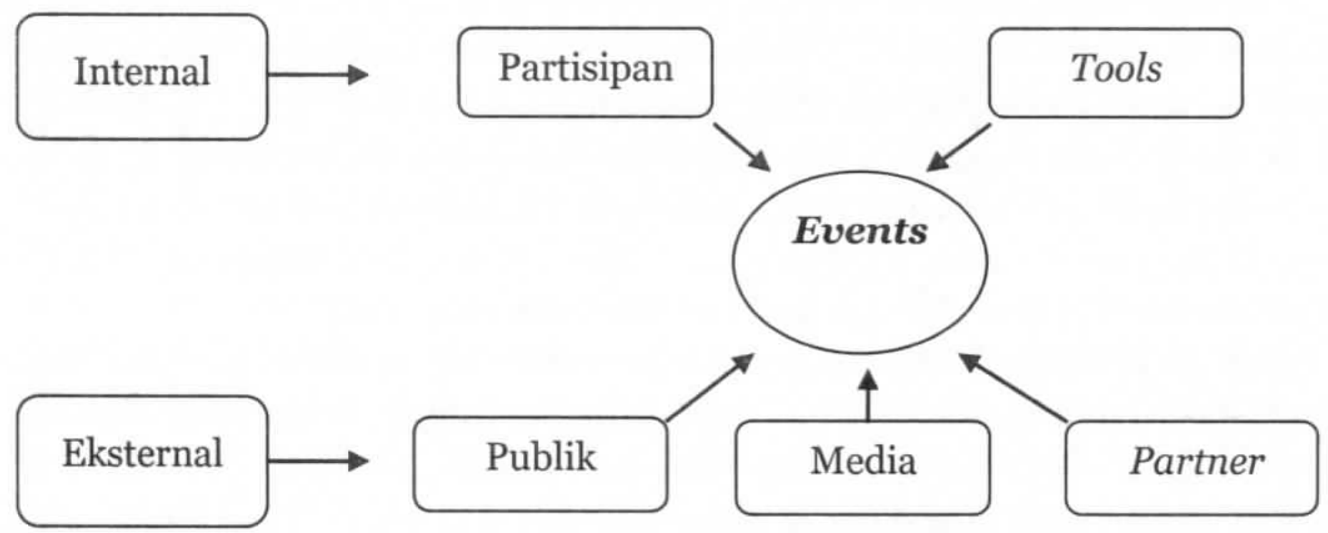

Gambar 1. Hubungan antara Event Olahraga dan Faktor Pendukung 
Olahraga dalam sistem ekonomi memunyai makna ganda, yaitu sebagai sebuah komoditas, dapat pula sebagai media pemasaran, atau bahkan sebagai pasar itu sendiri (Anwar dan Saryono, 2005: 105). Pada saat ini, olahraga sudah menjadi sebuah komoditas yakni layaknya sebagai barang yang laku untuk diperjualbelikan. Pangsa pasarnya pun relatif tinggi, baik itu berupa sebuah komoditas entertainment (dalam bisnis pertunjukkan) maupun sebagai komoditas yang dijual untuk dilakukan sebagai sebuah aktivitas rekreatif, terapi, prestasi, atau untuk menjaga kebugaran (fitness).

Pertandingan sepak bola merupakan salah satu contoh olahraga sebagai sebuah komoditas entertainment yang mempunyai daya tarik luar biasa bagi media massa, baik cetak maupun elektronik untuk meliputnya. TVRI dan beberapa TV swasta, seperti RCTI dan SCTV bersaing ketat untuk mendapatkan hak siar event olahraga perhelatan akbar sepak bola Piala Dunia. Dalam Piala Dunia 2006, di Jerman, SCTV menjadi satu-satunya pemegang hak siar seluruh pertandingan. Sebaliknya, dalam Piala Dunia 2010, di Afrika Selatan, RCTI dan Global TV berhasil memenangkan tender untuk memegang hak siar seluruh pertandingan.

Josep Maguire yang dilansir oleh Mutohir (2003: 99) memaparkan sebuah fenomena yang kian kompleks tentang kaitan kegiatan olahraga dengan media termasuk organisasi promosi/marketing yang menunjukkan pertumbuhan ke arah saling bergantung dalam sebuah konfigurasi mendunia yang mereka sebut dengan media/sport production complex. Olahraga sebagai komoditas untuk dilakukan itu dapat berbentuk jasa penjualan kegiatan dan fasilitas olahraga yang dioperasikan secara bisnis, seperti fitness centre, sekolah sepak bola, dan body building.

Sementara itu, yang dimaksud dengan olahraga sebagai media adalah pemanfaatan olahraga sebagai media pemasaran produk. Para produsen menyadari bahwa olahraga bak magnet yang mampu menyedot perhatian banyak orang dari segala lapisan, baik sebagai partisipan maupun sebagai penonton. Oleh karena itu, banyak perusahaan besar yang tidak ragu-ragu lagi untuk menjadi sponsor dalam setiap penyelenggaraan event olahraga untuk memasarkan produknya. Misalnya, perusahaan minuman Coca-Cola menjadi sponsor pertandingan sepak bola Piala Dunia, perusahaan elektronik LG mau menjadi sponsor balap mobil Formula 1, dan perusahaan rokok Djarum berani menjadi sponsor utama kompetisi sepak bola Liga Super Indonesia. Kendatipun mereka harus mengeluarkan biaya yang besar untuk menggelar event olahraga tersebut, keuntungan yang akan mereka peroleh dari event olahraga tersebut jauh lebih besar lagi.

Istilah pasar meliputi semua pelanggan potensial yang memiliki kebutuhan atau keinginan tertentu serta mau dan mampu turut dalam pertukaran untuk memenuhi kebutuhan atau keinginan. Besarnya pasar bergantung pada jumlah orang yang memiliki kebutuhan, punya sumber daya yang diminati orang lain, dan mau menawarkan sumber daya itu untuk ditukar supaya dapat memenuhi kebutuhan mereka (Nugroho, 2005: 78). Olahraga sebagai pasar berarti olahraga menjadi pelanggan sebuah produk perusahaan tertentu. Cabang olahraga atletik merupakan pasar dari perusahaan sepatu Nike yang berhasil

MEDIKCRA Vol. VI, No. 2, November 2010:55 - 63 
mengungguli Adidas dalam mengidentifikasi segmen pasar. Nike berhasil meningkatkan angka penjualannya dengan melayani segmen pasar yang belum sepenuhnya dilayani oleh Adidas, yaitu para jogger. Inilah yang dimaksud dengan olahraga sebagai "pasar" dalam pemasaran olahraga. Sebagai sebuah tontonan/entertainment, cabang olahraga atletik tidak mempunyai nilai jual yang tinggi, jika dibandingkan dengan cabang olahraga lainnya (sepak bola, bola basket, tenis, atau bulu tangkis). Meskipun demikian, dari segi pemanfaatan alat hasil pabrik, cabang olahraga atletik merupakan pangsa pasar yang sangat besar.

\section{Pemasaran Olahraga}

Olahraga merupakan media kegiatan pemasaran yang cukup kuat dalam merebut hati konsumen. Jika digarap dengan sungguh-sungguh, pemasaran olahraga (sport marketing) mempunyai daya tarik yang sangat ampuh bagi pemasar dalam upaya memperkuat brand awareness dan brand image konsumen (Ilhamdi, 2008: 1). Kemeriahan pertandingan, pakaian mentereng, aksesoris lainnya yang membuat panggung pertandingan menjadi gemerlap, merupakan objek empuk untuk dikemas dan disiarkan kepada khalayak yang haus akan hiburan. Berbagai event olahraga, seperti Kompetisi Liga Djarum Indonesia, Copa Indonesia, Piala Coca-Cola, Indonesian Basket Ball League, Tennis Commenwealth WTA, Speedy Tour d'Indonesia, dan kegiatan olahraga lainnya yang masih berjalan merupakan bukti nyata bahwa perkembangan pemasaran olahraga di Indonesia terus mengalami peningkatan, baik dari sisi kualitas maupun kuantitas.

Pemasaran olahraga tidak hanya berbicara tentang mengelola pemasarannya tetapi juga bagaimana mengelola entertainment menjadi sebuah produk pemasaran, baik secara teknis maupun nonteknis. NBA, liga bola basket Amerika terkemuka di dunia, dari sisi teknis mereka menampilkan permainan tim yang menghibur, yang kadang-kadang sudah keluar dari pakem/text boox. Semua itu sengaja dilakukan untuk menghibur dan memiliki nilai jual agar timnya digemari oleh para fans. Dari sisi nonteknis, penonton bola basket dapat melihat gerakan cheerleader yang atraktif dan menghibur di sela-sela waktu istirahat pemain yang juga memiliki nilai jual, sehingga keseluruhan acara NBA memiliki daya jual yang bagus di mata beberapa perusahaan agar menanamkan investasi mereka di Liga Bola basket tersebut.

Menurut Kotler (1995: 15) yang dimaksud dengan pemasaran adalah proses perencanaan dan pelaksanaan dari perwujudan, pemberian harga, promosi dan distribusi dari barang/jasa dan gagasan untuk menciptakan pertukaran dengan kelompok sasaran yang memenuhi tujuan pelanggan dan organisasi. Lebih lanjut dikatakan bahwa dalam pemasaran perlu ada manajemen pemasaran, yaitu suatu proses yang mencakup analisis, perencanaan, pelaksanaan, dan pengawasan yang meliputi barang atau jasa serta gagasan berdasarkan pertukaran dan tujuannya dengan memberikan kepuasan bagi para pihak yang terlibat. Dengan demikian, manajemen pemasaran olahraga dapat diartikan sebagai suatu proses analisis perencanaan, pelaksanaan, dan pengendalian tentang produk/jasa, harga, promosi, distribusi/penyampaian, fasilitas fisik, orang, proses, dan janji yang diberikan untuk memenuhi kebutuhan individu atau organisasi. 
Berkaitan dengan konsep dan masalah pemasaran, Dae Hwan Ok (2001) yang dikutip oleh Mutohir (2003: 66) mengatakan pemasaran olahraga dapat diklasifikasikan dalam beberapa sudut pandang: (1) pemasaran olahraga diartikan sebagai pemasaran langsung aneka hal yang berkaitan dengan olahraga, seperti pemasaran atlet, pemasaran pertandingan, dan pemasaran liga, (2) pemasaran itu dapat berlangsung melalui olahraga, seperti yang dilaksanakan oleh pełusahaan dalam rangka menjual produk olahraga atau nonolahraga.

Salah satu syarat supaya barang/jasa laku jual dan diakui pasar, barang/jasa tersebut harus memiliki kualitas yang baik. Kualitas event olahraga dibangun oleh faktor internal (partisipan dan tools) dan didukung oleh faktor eksternal (publik, media, dan partner). Penyelenggaraan event olahraga hanya akan diketahui oleh masyarakat luas kalau itu dipublikasikan melalui media massa, baik cetak maupun elektronik. Media massa bersedia mempromosikan event olahraga yang berkualitas tinggi karena itu memunyai nilai jual yang tinggi pula, dengan harapan ia akan memperoleh keuntungan dari pihak sponsor yang mendanai event tersebut.

Menurut Akadun (2004: 7) ada beberapa syarat yang harus dipenuhi untuk menjadikan event olahraga sebagai lahan bisnis, di antaranya: (1) masyarakat sudah memiliki kesadaran bahwa olahraga dapat membugarkan tubuh dan jiwa, meningkatkan kecerdasan, meningkatkan produktivitas kerja, dan mengurangi biaya perawatan kesehatan, (2) tingkat kesejahteraan masyarakat sudah relatif tinggi, sehingga masyarakat tidak hanya bergelut dengan pemenuhan kebutuhan primer, tetapi sudah memerlukan kebutuhan tersier, seperti rekreasi dan tontonan, (3) para penguasa sudah menyadari potensi dan peluang bisnis dari sebuah event olahraga, dan (4) pemilik modal, pengurus organisasi keolahragaan, dan pelaku olahraga mempunyai jiwa wirausaha, di samping mencintai olahraga dan rela berkorban baik tenaga maupun materi.

Untuk memasarkan barang/jasa diperlukan strategi khusus pemasaran yang dikenal dengan bauran pemasaran, yaitu kiat kelompok pemasaran yang digunakan perusahaan barang/jasa untuk mencapai sasaran pemasarannya dalam pasar sasaran. Setelah perusahaan barang/jasa menentukan pasar sasaran dan menentukan posisi yang akan didudukinya di pasar sasaran, langkah berikutnya adalah merancang strategi bauran pemasaran. Menurut Sucherly (1999: 10) ada dua macam bauran pemasaran, yaitu:

1. Bauran Pemasaran Barang, terdiri atas:

a. Product (produksi barang)

b. Price (harga barang)

c. Place (tempat/penyaluran barang)

d. Promotion (iklan, wiraniaga, humas, pemasaran langsung)

2. Bauran Pemasaran Jasa, terdiri atas:

a. Product (produk jasa)

b. Price (harga jasa)

c. Place/Delivery (tempat/penyaluran jasa) 
d. Promotion (iklan, wiraniaga, humas, pemasaran langsung)

e. Physical Evidence (dukungan fasilitas fisik, yaitu design, aestheties)

f. Process (serangkaian tahapan yang berkaitan dengan pelanggan)

g. People/Participants (karyawan, instruktur, pelanggan, komunikasi)

Dalam penerapannya, untuk memasarkan peralatan olahraga, seperti: raket, bola, stick golf, decker, dan alat-alat fitness perlu diperhatikan bauran pemasaran produk, yaitu: (1) bentuk fisik produk peralatan olahraga, (2) harga dan diskon yang ditawarkan, (3) sasaran konsumen, dan (4) saluran promosi melalui TV dan advertising. Untuk memasarkan jasa olahraga, misalnya fitness centre, perlu diperhatikan bauran pemasaran jasa, yaitu: (1) produk jasa fitness centre, (2) harga dan diskon yang diberikan, (3) tempat latihan yang strategis, (4) saluran promosi melalui TV dan advertising, (5) dukungan fasilitas fisik, seperti peralatan modern dan konsultasi dokter gratis, (6) proses keterlibatan member dalam menentukan program latihan, dan (7) instruktur yang menangani fitness centre cantik, menarik, dan sangat profesional (Nugroho, 2005: 79-80).

\section{Peran Media dalam Pemasaran Olahraga}

Olahraga sebagai kegiatan masyarakat luas memiliki daya tarik yang luar biasa dan sangat menakjubkan ketika dilakukan dengan orientasi dan tujuan yang sesuai dengan sifat manusia sebagai bomoludens. Kelebihan sifat ini membuat hampir seluruh media menyediakan ruang khusus untuk olahraga. Bagi media, olahraga memiliki sifat ganda, yaitu sebagai berita dan sebagai entertainment atau hiburan. Di satu sisi, masyarakat dengan berbagai motivasinya melakukan dan menyaksikan kegiatan olahraga untuk mendapatkan kesehatan, prestasi, hiburan, relasi, dan sebagainya. Tidak pelak lagi, olahraga secara alami merupakan kegiatan gerak dinamis manusia yang memiliki citra positif. Oleh karena itu, banyak negara di dunia menjadikan olahraga sebagai alat pemersatu bangsa, perdamaian, dan pembangunan karakter (Lumintuarso, 2005: 12). Image masyarakat yang baik terhadap kegiatan olahraga merupakan modal yang besar bagi media untuk mempromosikan produk-produk perusahaan melalui berbagai event olahraga, baik tingkat nasional maupun internasional.

Antara media massa dan olahraga mempunyai hubungan resiprokal, keduanya saling berpengaruh dan saling bergantung atas kesuksesan komersial dan popularitas (Coakley, 1994: 334-335). Popularitas olahraga meningkat karena ditayangkan dan diberitakan oleh media massa secara intensif dan kontinu. Rakyat Amerika Serikat begitu menggandrungi olahraga baseball, football, hoki es, dan bola basket, karena media massa mempromosikan dan memberitakan secara besar-besaran kegiatan tersebut pada awal perkembangannya. Kompetisi bola basket NBA bisa dinikmati dan digandrungi oleh sebagian masyarakat Indonesia karena ditayangkan dan diberitakan oleh media massa di Indonesia.

"Kegilaan" masyarakat (penonton) melihat tayangan event olahraga melalui televisi memberikan keuntungan finansial bagi pihak sponsor yang rela membayar milyaran rupiah kepada TV pemilik hak siar untuk mengiklankan produknya. Sudah dapat dipastikan 
bahwa nilai jual produk perusahaan yang menjadi sponsor event olahraga tersebut meningkat tajam. Sudah disebutkan di bagian lain, bahwa dengan menjadi sponsor dari berbagai event olahraga, angka penjualan produk LG di seluruh dunia berkembang dari US $\$ 100$ juta menjadi US $\$ 43,3$ miliar.

Pada zaman kebebasan pers seperti sekarang ini, peran media massa sangat dominan dalam membentuk ppini masyarakat (public opinion). Semua hal yang diberitakan melalui media massa dengan cepat ditangkap oleh masyarakat untuk dijadikan pebincangan dan sebagian melekat menjadi persepsi yang diyakini. Oleh Ibrahim dan Idi Subandi (1997: 35) dikatakan bahwa dalam tayangan TV tidak hanya terjadi proses pencitraan, tetapi juga estetikasi dan bahkan pembentukan ideologi masyarakat. Produk perusahaan yang secara intensif dan kontinu diberitakan dan ditayangkan oleh media massa, baik cetak maupun elektronik, akan menumbuhkan brand image dan fanatisme yang luar biasa bagi masyarakat. Orang menjadi begitu fanatik dengan produk tertentu untuk perlengkapannya, sehingga mereka tidak mau memakai produk sepatu, kaos, celana, atau topi lainnya kalau bukan yang bermerek Adidas, misalnya.

\section{PENUTUP}

Seiring dengan pola orientasi dunia baru yang dicirikan oleh akselerasi perkembangan teknologi yang pesat, terutama teknologi informasi dan berbagai gaya hidup yang membaur serta trend dunia satu, globalisasi muncul sebagai keniscayaan yang terjadi di seluruh kehidupan, termasuk aspek ekonomi dan industri. Dalam era globalisasi ini, muncul sebuah terminologi, sportainment yang mengkonfirmasikan fakta bahwa olahraga bukan lagi sekedar olah tubuh melainkan juga sebuah industri hiburan dan bisnis pertunjukan yang mengundang ribuan penonton (secara langsung) dan jutaan pemirsa (melalui media).

Olahraga merupakan lahan bisnis yang teramat subur bagi para produsen untuk mempromosikan produk-produk mereka kepada konsumen, sehingga dalam waktu yang relatif cepat dan mudah dapat diraih keuntungan finansial yang besar. Dengan meningkatnya kegiatan olahraga, kebutuhan masyarakat akan produk dan peralatan olahraga pun menjadi semakin meningkat. Media massa, baik cetak maupun elektronik, mempunyai peran yang besar dalam mempromosikan produk dan peralatan olahraga secara intensif dan kontinu melalui berita dan tayangan TV yang dikemas dalam satu paket dengan event olahraga.

Kualitas event olahraga merupakan faktor utama yang perlu diperhatikan dalam kaitannya dengan aspek pemasaran, karena hanya event olahraga yang bermutu tinggi yang mempunyai nilai jual. Oleh sebab itu, dalam memasarkan event olahraga perlu dipikirkan strategi pemasaran, sehingga komoditas yang dipasarkan dapat menjangkau pangsa pasar yang diharapkan. Pemasaran olahraga mempunyai kekuatan yang luar biasa untuk menciptakan brand awareness kepada konsumen sehingga dalam dirinya tumbuh fanatisme terhadap produk tertentu.

Di samping itu, pemasaran olahraga merupakan faktor yang sangat penting untuk membangun industri olahraga. Oleh sebab itu, dalam rangka membangun industri olahraga 
di Indonesia, pemasaran olahraga perlu digalakkan, di samping melakukan diversifikasi industri olahraga dan diversifikasi sumber daya olahraga. Dasar hukumnya sudah ada, yaitu Undang-Undang Nomor 3 Tahun 2005, tentang Sistem Keolahragaan Nasional, Pasal 78, 79, dan 80, tunggu apa lagi?!

\section{DAFTAR PUSTAKA}

Akadun. (2004). "Bisnis dan Manajemen Olahraga." Suara Merdeka. (9 Septem-ber 2004). Hlm. 7.

ANG. (2010). "Piala Dunia 2010 Sukses: Keuntungan Sponsor dan Jumlah Pemirsa Melonjak." Kompas. (14 Juli 2010). Hlm. 31.

Anwar, Hamid dan Saryono. (2005). "Sport Marketing sebagai Penjawab Masalah Klasik Kekurangan Dana dalam Olahraga." Proceeding Seminar Nasional. Yogyakarta: FIK UNY.

Azra, Azyumardi. (2010). "Ekonomi Politik Piala Dunia 2010.” http://cetak.kom-pas.com/ read/xml/2010/06/14/03542010/ekonomi.politik.piala.dunia.2010

Biro Humas dan Hukum. (2007). Undang-Undang Republik Indonesia Nomor 3 Tabun 2005 tentang Sistem Keolabragaan Nasional. Jakarta: Biro Humas dan Hukum Kementerian Negara Pemuda dan Olahraga Republik Indonesia.

Burhanudin, M. (2010). "Pencitraan Produk Global." Kompas. (7 Oktober 2010). Hlm. 33.

Coakley, Jay L. (1994). Sport in Society: Issues and Controversies. $5^{\text {th }}$. ed. St. Louis, Toronto: Mosby-Year Book, Inc.

Ibrahim dan Idi Subandi. (1997). Bercinta dengan Televisi. Bandung: Remaja Rosda Karya.

Ilhamdi. (2008). "Sports, Marketing, dan Entertainment." bttp://121.52.132.148/ berita.php? $=20$ erjd $=$ Sports $\% 2 C+$ Marketing + dan + Entertainmente $d n=20080328234357$

Kotler, Philip \& Armstrong, Gary. (1995). Marketing Management: Analysis, Planning, Implementation, and Control. Englewood Cliffs: Prentice-Hall International, Inc.

Lumintuarso, Ria. (2005). “Globalisasi Industri Olahraga.” Makalab Seminar. Yogyakarta: FIK UNY.

Mutohir, Toho Cholik. (2003). Olabraga, Kebijakan dan Politik: Sebuah Analisis. Jakarta: Proyek Pengembangan dan Keserasian Kebijakan Olahraga, Ditjen Olahraga, Depdiknas.

(2004). Olahraga dan Pembangunan: Meraib Kembali Kejayaan. Jakarta: Proyek Pengembangan dan Keserasian Kebijakan Olahraga, Ditjen Olahraga, Depdiknas.

Nugroho. (2005). "Bisnis Industri Olahraga dan Strategi Pemasaran." Proceeding Seminar Nasional. Yogyakarta: FIK UNY.

Sucherly. (1999). Manajemen Pemasaran Jasa. Bandung: Pasca Unpad. 